\title{
Development of a Scale to Assess Adequacy of Organizational Structure
}

\author{
Shanti Suman \\ Correspondence: Shanti Suman, Department of Psychology, University of Allahabad, Allahabad (UP), PIN- \\ 211002, India. Tel: 91-933-507-7920. E-mail: shanti_suman@ @rediffmail.com
}

\author{
Received: August 13, 2013 Accepted: August 24, 2013 Available online: November 15, 2013 \\ doi:10.11114/ijsss.v2i1.199 URL: http://dx.doi.org/10.11114/ijsss.v2i1.199
}

\begin{abstract}
The present study was undertaken to construct and validate a scale to assess the adequacy of organization structure. After studying each component of the organizational structure and discussion with experts, 21 items were selected and 5-point Likert-type scale was prepared. The scale was administered to 240 employees working in a well known production organization. The scale has desirable psychometric properties, including high internal consistency, reliability and construct validity. The scale satisfactorily validates with certain criterion measures, such as organizational commitment, job satisfaction and work motivation.
\end{abstract}

Keywords: Organizational Structure, Scale

\section{Introduction}

The structure of an organization plays a very important role to fulfil its functions (Nelson \& Quick, 2011). The term organizational structure refers to the formal configuration between individuals and groups regarding the allocation of tasks, responsibilities, and authority within the organization (Galbraith, 1987; Greenberg, 2011). Earlier organizational structures were based either on product or function (Oliveira \& Takahashi, 2012). Lunenburg (2012) reported landmark approach developed by Chandler $(1962,2003)$ which moved beyond these early approaches and examined the relationship between organizational strategy and structure (Brickley, Smith, Zimmerman \& Willett, 2002).

An organizational structure is a mostly hierarchical concept of subordination of entities that collaborate and contribute to improve effectiveness of an organization. The formation of organizational structure mainly depends upon objectives and environment of an organization. It determines the modes in which it operates and performs. An inadequate organizational structure decreases performance and may hamper cooperation among employees within the organization. Adequate organizational structures are intending to optimize the overall functioning of an organization and facilitate working relationships between various entities in the organization.

The importance of adequate organizational structure, discussed above, draw attention of organizational psychologists to study it minutely. First, they tried to define the concept of organizational structure properly. Organizational structure, defined as "the recurrent set of relationships between organization members" (Donaldson, 1996), has been proposed to be composed of both mechanistic and organic forms (Stopford \& Baden-Fuller, 1994). Mechanistic structures are rigid and tight, indicative of traditional bureaucratic environments. In such contexts, centralized power is common; communication is funnelled through rigid hierarchical channels, whereas job descriptions and decision-making styles are highly uniform and formal. On the opposite end of the structural continuum, organic environments are flexible, loose and decentralized, with open and informal communication pattern. This type of structure allows employees the flexibility to adapt (Ambrose \& Schminke, 2003).

Bacharach and Aiken (1976) have defined organizational structure in terms of the morphology or shape of an organization. Similarly, Schneider (1975) stressed the observable or tangible aspects of an organization. Among the more tangible aspects of an organizational structure are size, work rules and policy (formalization), roles, number of levels in the organizational hierarchy and the extent of centralization. However, the perception of these objective structural properties is more important determinant of individual responses to the organization than is their objective reality.

The present study intended to develop a measure of organizational structure and has tried to incorporate the important dimensions relevant in work scenario. The main purpose of the present work is to construct and 
validate such a measure which could assess the adequacy of organizational structure; which in turn affects employees' job attitudes, like, job satisfaction, motivation and organizational commitment.

\section{Construction of the Scale}

A 21-items scale containing structural features of the organization was prepared to assess the extent of prevalence and adequacy of the major characteristics of organizational structure, such as size, formalization, departmentation, centralization, vertical and horizontal differentiation and span of control. Out of 21 items, 12 items are "true-keyed" while 9 items are "false-keyed". All items are to be responded on a five-point scale- 'strongly agree', 'Agree', 'Uncertain', 'Disagree' and 'Strongly disagree'. Score on this scale varies from 21 to 105.

\subsection{Samples for the Standardisation of the Scale}

In order to determine the applicability and homogeneity of the items the prepared questionnaire was individually administered to a randomly selected sample of 240 employees working in Bokaro Steel Plant, Bokaro (Jharkhand, India), a well-known production organization and one of the five integrated plant of the Steel Authority of India Ltd. (SAIL). They were drawn from the different units of the organization. The participants' age ranged from 23 years to 58 years with an average of 39.35 years $(S D=9.89)$. The participants in average possessed the work experience of 13.33 years $(S D=9.09)$ in the range of 1 to 34 years. The participants themselves responded to the questionnaire, however, they were helped when it was required by some of them.

\subsection{Item Analysis}

The psychometric properties of the organizational structure scale were evaluated using three indices, namely, 'corrected item-total correlation', 'squared multiple correlation' and 'alpha if item deleted'. The psychometric properties of this scale have been presented in the Table 1.

'Corrected item-total correlation' is the conventional technique of item analysis, which provides an index of item homogeneity (validity), however, the 'squared multiple correlation' is considered better technique for evaluating the item validity inasmuch as it provides an index of the proportion of the total variance in a given item explained by the remaining items. 'Alpha if item deleted' is used as an index of item reliability. If the reliability of the scale after deleting a given item increases (as compared to the full scale reliability), it suggests that the given item is psychometrically poor.

The observation of the psychometric properties of the scale, presented in Table 1, suggests that all the items are positively and significantly correlated with the total score ('corrected item-total correlation' ranged from .2534 to .4964 ), which suggests that all of them measure the same trait, i.e., organizational structure.

Table 1. Psychometric Properties of the Organizational Structure Scale

\begin{tabular}{cccc}
\hline $\begin{array}{c}\text { Serial Number of the } \\
\text { Items }\end{array}$ & $\begin{array}{c}\text { Corrected Item-Total } \\
\text { Correlation }\end{array}$ & Squared Multiple Correlation & $\begin{array}{c}\text { Alpha if Item } \\
\text { Deleted }\end{array}$ \\
\hline 1 & .4406 & .4561 & .7936 \\
2 & .3485 & .3933 & .7990 \\
3 & .3608 & .3930 & .7983 \\
4 & .2631 & .3927 & .8037 \\
5 & .2925 & .3718 & .8021 \\
6 & .3500 & .3569 & .7989 \\
7 & .4475 & .3392 & .7936 \\
8 & .3345 & .4245 & .7997 \\
9 & .4581 & .3782 & .7927 \\
10 & .4964 & .4890 & .7907 \\
11 & .2534 & .2021 & .8039 \\
12 & .3171 & .4923 & .8006 \\
13 & .3990 & .5520 & .7965 \\
14 & .4074 & .4709 & .7959 \\
15 & .2875 & .2133 & .8026 \\
16 & .3672 & .2971 & .7980 \\
17 & .3228 & .2990 & .8004 \\
18 & .4335 & .3677 & .7948 \\
19 & .3629 & .3629 & .7982 \\
20 & .3304 & .3304 & .8001 \\
21 & .3672 & .3672 & .7980 \\
\hline
\end{tabular}


The 'squared multiple correlation' (ranged from .2021 to .5520) indicates that the items of this scale are valid since $20.21 \%$ to $55.20 \%$ of the total variance in various items can be explained by the remaining twenty items. Overall, the 'corrected item-total correlation' and 'squared multiple correlation' suggest that the organizational structure scale is composed of homogeneous item-pool. Perusal of the 'alpha if item deleted' indicated all items in this scale have strong psychometric property, because its value for each item is less than the alpha of full scale, i.e., .81 .

\subsection{Inter-Dimension Homogeneity}

The intercorrelations among different dimensions of the scale, presented in Table 2, have been found to be significantly high. The obtained $\mathrm{r}$ values indicate high construct validity of the scale.

Table 2. Intercorrelations among the Subscales of the Organizational Structure Scale

\begin{tabular}{|c|c|c|c|c|c|c|c|}
\hline Sub- Scales & 1 & 2 & 3 & 4 & 5 & 6 & 7 \\
\hline \multicolumn{8}{|l|}{ Adequate Size (1) } \\
\hline Formalization (2) & $.43^{* *}$ & & & & & & \\
\hline Departmentation (3) & $.22^{* *}$ & $.21^{* *}$ & & & & & \\
\hline Centralization (4) & $-.49^{* *}$ & $-.54^{* *}$ & $-.33^{* *}$ & & & & \\
\hline Vertical and Horizontal Differentiation (5) & $-.04^{* *}$ & $.24^{* *}$ & $.42^{* *}$ & $-.23^{* * *}$ & & & \\
\hline Moderate Level of Span of Control (6) & $.39^{*}$ & $.36^{* *}$ & $.29^{* *}$ & $-.42^{* *}$ & $.21^{* *}$ & & \\
\hline Good Communication Pattern (7) & $.14^{* *}$ & $.28^{* *}$ & $.20^{* *}$ & $-.39^{* *}$ & $.26^{* *}$ & $.29^{* *}$ & \\
\hline Over all Adequacy of Organizational Structure & $.54^{* *}$ & $.74^{* *}$ & $.55^{* *}$ & $-.78^{* *}$ & $.55^{* *}$ & $.69^{* *}$ & $.55^{* *}$ \\
\hline
\end{tabular}

The correlation coefficients between different dimensions of organizational structure reveal that all positive dimensions of organizational structure (i.e., adequate size, formalization, departmentation, vertical and horizontal differentiation, moderate level of span of control and good communication pattern) are positively correlated with each other (barring adequate size and vertical and horizontal differentiation, which have very low negative correlation value). On the other hand, all positive dimensions are negatively correlated with negative dimension of organizational structure (i.e., centralization).

\subsection{Reliability}

The reliability of the scale was determined using Cronbach's alpha (Cronbach, 1951), which was found to be .81, suggesting that scale is highly internally consistent (reliable).

\subsection{Validity}

Apart from 'Corrected item-total correlation' and 'squared multiple correlation' for evaluating the item validity (shown in Table 1), the validity of the scale was also assessed by examining its correlation with three external criteria- organizational commitment, job satisfaction and work motivation.

Table 3. Correlations between Different Dimensions of Organizational Structure Scale and Organizational Commitment, Job Satisfaction and Work Motivation

\begin{tabular}{lccc}
\hline Dimensions of Organizational Structure Scale & Organizational Commitment & Job Satisfaction & Work Motivation \\
\hline Adequate Size & $.32^{* * *}$ & $.28^{* *}$ & $.23^{* *}$ \\
Formalization & $.42^{* *}$ & $.39^{* *}$ & $.32^{* *}$ \\
Departmentation & $.32^{* *}$ & $.25^{* *}$ & $.34^{* *}$ \\
Centralization & $-.46^{* *}$ & $-.40^{* *}$ & $-.29^{* *}$ \\
Vertical and Horizontal Differentiation & $.29^{* *}$ & $.27^{* *}$ & $.31^{* *}$ \\
Moderate Level of Span of Control & $.41^{* *}$ & $.32^{* *}$ & $.31^{* *}$ \\
Good Communication Pattern & $.25^{* *}$ & $.25^{* *}$ & $.20^{* *}$ \\
Over all Adequacy of Organizational Structure & $.57^{* *}$ & $.49^{* *}$ & $.45^{* *}$ \\
\hline${ }^{* *} p<.01$ & & &
\end{tabular}

The scores obtained on Organizational Commitment Questionnaire (Mowday, Steers, \& Porter, 1979), S-D Employees Inventory (Pestonjee, 1973) and Employees Motivation Schedule (Srivastava, 1986) were used in the analysis. The obtained correlations between these three external criteria and different dimensions of the scale, presented in Table 3, indicate satisfactory concurrent validity of the scale.

\subsection{Scoring}

The score on each item of the scale ranges from 1 to 5 . The scores for five alternative responses to each item are shown in Table 4. 
Table 4. Scores for items

\subsection{Norms}

\begin{tabular}{lcc}
\hline \multirow{2}{*}{ Responses } & \multicolumn{2}{c}{ Scores } \\
\cline { 2 - 3 } & True-Keyed Items & False-Keyed Items \\
\hline Strongly agree & 5 & 1 \\
Agree & 4 & 2 \\
Uncertain & 3 & 3 \\
Disagree & 2 & 4 \\
Strongly disagree & 1 & 5 \\
\hline
\end{tabular}

Raw score norms have been attempted for interpretation of the results. The norms have been developed on the total sample of 240 employees. No attempt has been made to give norms for gender-wise or any other classification. Table 5 shows the raw score norms for the job characteristics scale.

Table 5. Raw Score Norms for the Organizational Structure Scale

\section{Limitations}

\begin{tabular}{lr}
\hline Classification & Range of Scores \\
\hline Inadequate Structure & $21-48$ \\
Moderately Adequate Structure & $49-76$ \\
Highly Adequate Structure & $77-105$ \\
\hline
\end{tabular}

The present Organizational Structure Scale was developed within the constraints of time, human and material resources available. Raw score norms were only developed for the interpretation of the results. The sample were drawn from a production organization, no attempt was made to develop norms for other type of organizations.

\section{References}

Ambrose, M. L., \& Schminke, M. (2003). Organization structure as a moderator of the relationship between procedural justice, interactional justice, perceived organizational support, and supervisory trust. Journal of Applied Psychology, 88, 295-305. http://dx.doi.org/10.1037/0021-9010.88.2.295

Bacharach, S. B., \& Aiken, M. (1976). Structural and process constraints on influence in organizations: A level specific analysis. Administrative Science Quarterly, 21, 623-642. http://dx.doi.org/10.2307/2391720

Brickley, J., Smith, C., Zimmerman, J. L., \& Willett, J. (2002). Designing organizations to create value: From strategy to structure. New York, NY: McGraw-Hill.

Chandler, A. D. (1962). Strategy and Structure. Cambridge, MA: MIT Press.

Chandler, A. D. (2003). Strategy and Structure: Chapters in the history of the American industrial enterprise. Frederick, MD: Beard Books.

Cronbach, L. J. (1951). Coefficient alpha and the internal structure of tests. Psychometrika, 16, 297-334. http://dx.doi.org/10.1007/BF02310555

Donaldson, L. 1996. The normal science of structural contingency theory. In S. R. Clegg, C. Hardy, \& W. R. Nord (Eds.), Handbook of organizational studies, 57-76. Thousand Oaks, CA: Sage.

Galbraith, J. R. (1987). Organization design. In J. W. Lorsch (Ed.). Handbook of organizational behavior (pp. 343-357). Englewood Cliffs, NJ: Prentice Hall.

Greenberg, J. (2011). Behavior in organizations (10 ${ }^{\text {th }}$ ed.). Upper Saddle River, NJ: Prentice Hall.

Lunenburg, F. C. (2012). Organizational structure: Mintzberg's framework. International Journal of Scholarly, Academic, Intellectual Diversity, 14, 1-8.

Mowday, R. T., Steers, R. M., \& Porter, L. W. (1979). The measurement of organizational commitment. Journal of Vocational Behavior, 14, 224-247. http://dx.doi.org/10.1016/0001-8791(79)90072-1

Nelson, D. B., \& Quick, J. C. (2011). Understanding organizational behavior. Mason, OH: South-Western Cengage Learning.

Oliveira, N., \& Takahashi, N. (2012). Automated organizations: Development and structure of the modern business firm. New York, NY: Springer. http://dx.doi.org/10.1007/978-3-7908-2759-0

Pestonjee, D. M. (1973). Organizational structure and job attitudes. Kolkata, India: Minerva.

Schneider, B. (1975). Organizational climates: An essay. Personnel Psychology, 28, 447-479. http://dx.doi.org/10.1111/j.1744-6570.1975.tb01386.x 
Srivastava, A. K. (1986). Employees Motivation Schedule. Varanasi, India: Manovaigyanik Parikchhan Sasthan.

Stopford, J. M., \& Baden-Fuller, C. W. F. (1994). Creating corporate entrepreneurship. Strategic Management Journal, 15, 521-536. http://dx.doi.org/10.1002/smj.4250150703

\section{Appendix}

\section{Organizational Structure Scale}

Instructions: Following are the few statements to know the adequacy of structure of organization in which you are working. There are five options against each statement, give your response by putting a tick mark $(\sqrt{ })$ in any one of them. Please respond to all statements.

1. This organization is so much large that it is difficult to establish coordination between different departments.

2. All rules related with work and employees are well written in this organization.

3. The rules and norm of this organization are very tuff and employees have to obey these.

4. It is continuously observed that employees obey rules related with the job.

5. There is very adverse result for violating the rules and processes of organization.

6. The division of work in this organization is clearly defined and logical.

7. Conflicting situation always be present in the absence of work related rules.

8. For the execution of different works, this organization is divided in many departments.

9. In this organization even smallest of the small policy is determined only by top-level authorities.

10. Whenever employees do important work, first, they have to ask their authority.

11. Policies of the organization are determined by mutual discussion.

12. In this organization, there are different officers employed for different departments and they all work under the guidance of chief executive.

13. In this organization, executives are categorised on the basis of hierarchical system and every executive is responsible for his senior.

14. In this organization, different experts are employed according to the nature of job.

15. Every executive in this organization has to control large number of employees, thus, effective control is not possible.

16. There is limited number of employees under each authority.

17. The information regarding every policy of this organization reaches very quickly to employees due to effective communication pattern within organization.

18. Information related with the policies of work is communicated to employees through established sources.

19. Here, authorities issue instructions and it is expected that it move forward without any interruption.

20. Employees do their work independently in good manner because authorities do not interfere.

21. In this organization, the suggestions of employees are well considered and they are also implemented.

\begin{tabular}{|c|c|c|c|}
\hline 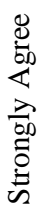 & 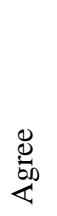 & 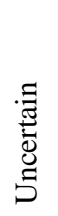 & 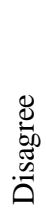 \\
\hline ( ) & ( ) & ( ) & ( ) \\
\hline ( ) & ( ) & ( ) & ( ) \\
\hline ( ) & ( ) & ( ) & ( ) \\
\hline ( ) & ( ) & ( ) & ( ) \\
\hline ( ) & ( ) & ( ) & ( ) \\
\hline ( ) & ( ) & ( ) & ( ) \\
\hline ( ) & ( ) & ( ) & ( ) \\
\hline ( ) & ( ) & ( ) & ( ) \\
\hline () & ( ) & ( ) & ( ) \\
\hline ( ) & ( ) & ( ) & ( ) \\
\hline ( ) & ( ) & ( ) & ( ) \\
\hline () & ( ) & ( ) & () \\
\hline ( ) & ( ) & ( ) & ( ) \\
\hline ( ) & ( ) & ( ) & ( ) \\
\hline ( ) & ( ) & ( ) & ( ) \\
\hline ( ) & ( ) & ( ) & ( ) \\
\hline () & ( ) & ( ) & ( ) \\
\hline ( ) & ( ) & ( ) & () \\
\hline () & ( ) & ( ) & ( ) \\
\hline () & ( ) & ( ) & () \\
\hline & ( ) & ( ) & ( ) \\
\hline
\end{tabular}

\section{(c) $\mathrm{BY}$}

This work is licensed under a Creative Commons Attribution 3.0 License. 